\title{
SOME OBSERVATIONS ON THE ROLE OF WATER STATES FOR BIOLOGICAL AND THERAPEUTICAL EFFECTS
}

\author{
M. Scalia ${ }^{1 *}$, P. Avino ${ }^{2,3}$, M. Sperini ${ }^{1}$, V. Viccaro ${ }^{4}$, A. Pisani ${ }^{2}$, V.I. Valenzi ${ }^{1,2,5}$ \\ ${ }^{1}$ Interuniversity Center of Research for Sustainable Development, Rome, Italy \\ 2International Committee for Research and Study of Environmental Factors, Belgium \\ ${ }^{3}$ Istituto Nazionale Assicurazione Infortuni sul Lavoro, Rome, Italy \\ ${ }^{4}$ EU.NA.M. Institute, Rome, Italy \\ ${ }^{5}$ UNIGLOBUS University Assisi, Assisi, Italy \\ *Corresponding author: massimo.scalia@uniroma1.it \\ Received 8 Juny 2018; Accepted 6 August 2018
}

\begin{abstract}
The peculiar properties of water are recalled, among them the "memory of water", underlining the behavior of cell water, whose "ordered" structure is probably due to the endogenous electromagnetic fields generated by organelles inside the cells, such mitochondria and microtubules. Biological and clinical implications of water dynamic changes are reported, mainly based on SEP (Skin Electric Parameters) analysis and a hypothesis that has been advanced about an "action at distance" exerted by low concentration drugs. Nowadays, regarding measures of electro-cutaneous parameters our research can resort to a device of advanced electronics, APEC 300, that, beside an Electro Acupuncture operational function, but with quantitative precise values, can detect micro variations on parameters of cell aqueous solutions, and those of the water too, when the analyzed object is solicited by an external electromagnetic weak field, as well as by a drug at a very low concentration. A draft of two possible lines of research is outlined in conclusions, one depending only on ourselves and regarding "water tests" in the context of the "memory of water" experiments. By the side of EIS experiments about conductivity and impedance spectroscopy, in this article very high-resolution measures are suggested, by means of APEC 300, of an important parameter, the potential; a kind of measurements less complex and more reliable regarding the device/object interference, to which can besides easily be associated a frequency spectrum in the extremely low frequency region. In this line of research, it is the first time, for what we know, that some measurements of the potential, with its frequency spectrum, have been carried out for water without and with stimulation (the latter represented by the action of a magnetic field). This first set of measures by APEC 300 reveals the region $0-0.5 \mathrm{~Hz}$ as one of special interest.

Keywords: cell water; water dynamic changes; biological and clinical implications; skin electric parameters; Electro Acupuncture of Voll; APEC 300 and high resolution measures; drugs at very low concentration; potential measurements and frequency spectrum; memory of water.
\end{abstract}

\section{Introduction}

How to explain several astonishing properties of water, the substance so strictly connected to life and its multiple forms? How do play endogenous electromagnetic fields in "ordering" cell water? Starting from these questions, after a brief recalling of magnetic properties of water and its "memory", we underline the central hypothesis enhanced by Herbert Fröhlich, who developed a theory of biological coherence based on quantum interactions between dipolar constituents of biomolecules, such as those of the enzymes, membranes, organelles and the same cells; a relevant feature of this theory is exactly the special structure supposed for the biologic water (micro-trabecular structure). This kind of reasoning has been a background for many other Physicists and Doctors, whose relevant contributions are recalled and quoted in references.

Up to now, we are faced with an abundance of theoretical models, some of them are briefly reported, mainly provided by Physicists, and a relative poorness of experimental data presented by Physicians. An exception can be represented by Reinhold Voll and its Electro Acupuncture (EAV), with experiments reported in scientific literature up to day. Dr. Voll theorized, on the basis of the experience of Chinese medicine, a tight link among the values of the Skin Electric Parameters (SEP) and the health status performance; and EAV is a diagnosis method to reveal pathophysiological processes, as inflammations, pain, allergy, gastrointestinal function, etc. 
Some few relevant clinic experiences are reported and commented, and, just in the perspective of a significant multiplication of rigorous experimental data, we present in the last section a research project, no more than a draft, on which is the case of spending few words. The implementation of the project is founded on a device of advanced electronics, APEC 300 that is an analyzer of electro-cutaneous parameters - impedance, potential realized in Rome by some researchers of Bioelectromagnetism (BEM) Section of the Interuniversity Center of Research for Sustainable Development (CIRPS). This apparatus can perform EAV, with a higher resolving power and a greater reliability of results than the traditional apparatus, and can measure, among several its applications, the skin potential level as function of time, besides providing its frequency spectrum at extremely low frequencies. It is worth to underline that APEC 300 can also measure bioelectric activity of cell cultures or aqueous solutions of drugs or pharmaceutical complexes (to assess their effectiveness or dangerousness).

In the last twenty years, much attention has been devoted to the behavior of aqueous solutions of cells, enzymes or more simple organic compounds when they are solicited by a very weak magnetic field. Many impedance measures have been realized, while a little attention has been given to the potential, perhaps due to the scarce reliability of the available measure instruments. Our idea is to exploit the high resolving power of APEC 300 to test not only aqueous solutions impedance, but also the potential; not only when aqueous solutions are submitted to an external magnetic field, but under the influence of a specific drug at a very low concentration. The further step would be to detect, in a collaboration with Physicians, the impedance response of a patient who has been given that drug at that concentration level, to be compared with the same response in absence of the drug assumption.

A not negligible part of the article regards "water tests" linked to "water memory" experiments. EIS devices for high-resolution detection of electrochemical properties of aqueous solutions are to be managed very cautiously, not only for reliability of measure but also to avoid device/object interference. Starting just from a comparison between tap water and stimulated tap water, the possibility of a more "at hand" measure method - that of measuring the variations of potential in frequency spectrum (up to less than 100 nanoVolt) - has obtained a first translation in practice by the set of measurements where the stimulation is given by the action of an alternating magnetic field at $50 \mathrm{~Hz}$ frequency (126.10 $\mu \mathrm{T}$ maximum intensity). Figures and data of the experiment are presented in the Annex. The measurements have been realized by APEC 300 and the corresponding frequency spectrum shows as a region of special interest the one from 0 to $0.5 \mathrm{~Hz}$. This occurrence was in somewhat manner expected due to a similar behavior recorded during the phase of improving and calibration of APEC 300, when biological objects like fruit or leaves (their skin) were used as test materials.

\section{The anomalies of water}

The water molecule, $\mathrm{H}_{2} \mathrm{O}$, consists of two hydrogen atoms linked to an oxygen atom by a polar covalent bond. The $\mathrm{H}-\mathrm{O}$ link distance is $0.958 \AA$ and the $\mathrm{O}-\mathrm{H}-\mathrm{O}$ binding angle is $104.45^{\circ}$. The arrangement of electrons in the molecule determines electrical asymmetry. The difference of electronegativity between $\mathrm{O}$ (3.44; one of the electronegative elements of the periodic table of the elements) and $H$ (2.20) makes the water molecule a permanent electric dipole of nature that allows the formation of hydrogen bonds between atoms of $\mathrm{H}$ of a molecule and atoms of $\mathrm{O}$ of other water molecules. The spatial structure of the water molecule is of tetrahedral geometry, with the $\mathrm{O}$ atom at the center of the tetrahedron (Fig. 1).

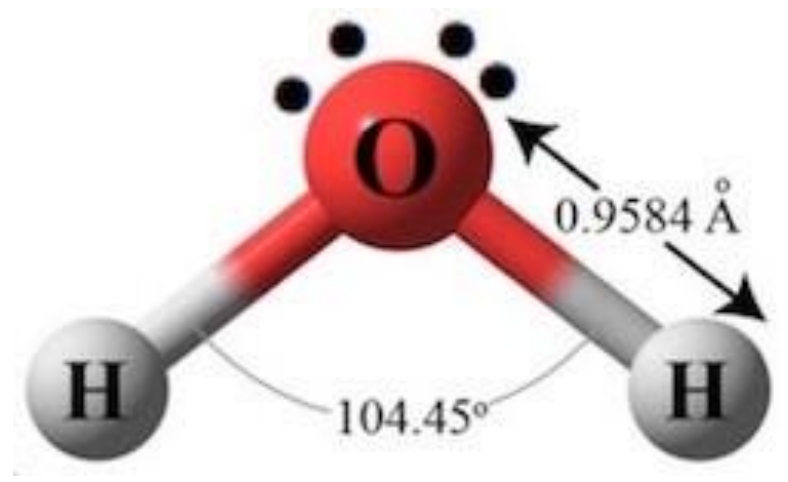

Figure 1: Spatial structure of water

All these peculiar features of water make it a unique molecule with physical and chemical properties that are still termed "abnormal" because of the inability to fully explain them even today.

Exceptional solvent, water is the life-giving molecule on Earth: it covers about $70 \%$ of the Earth's surface, accounts for $65 \%$ of a human and $90 \%$ of macromolecules present in biological systems. If the water did not exist, no chemical reac- 
tions, no transport of nutrients and waste, etc. would exist. In a word, without water, there would be no life.

Within the range of environmental temperature and pressure, water is found in all three physical aggregation states: solid (ice), liquid (liquid water) and aeriform (water vapor).

Most of the models proposed to explain the peculiar properties of water start from the study of an isolated water molecule, then extend its characteristics and behaviors to the water molecules bound to it. Each model aims to predict the behavior of water in its three aggregation states and subsequently verify its compatibility with experimental chemical-physical properties.

Problems arise when, through intermolecular electrostatic attraction forces (short-range forces), a lot of water molecules are assembled to form the liquid phase together. None of the water models proposed to date, based on short-range forces, is able to describe satisfactorily the "abnormal" chemical-physical behavior of water.

Density. It has been observed experimentally that the number of water molecules found in $1 \mathrm{~cm}^{3}$ of liquid in the range $0{ }^{\circ} \mathrm{C} \leq T \leq 4{ }^{\circ} \mathrm{C}$ increases instead of decreasing, water has its maximum density at $T=3.98{ }^{\circ} \mathrm{C}$ and not at $0{ }^{\circ} \mathrm{C}$.

Viscosity. It gives a measure of the force that obstructs the sliding of the molecules with respect to each other, is linked to intermolecular forces and depends on temperature and pressure: generally decreases as temperature rises and decreases in pressure. The viscosity of the water decreases as the temperature rises, as expected, but increases as the pressure decreases. In more detail: for liquid water at $T<30{ }^{\circ} \mathrm{C}$, increasing the pressure viscosity begins to decrease; then continuing to increase the pressure the abnormal trend ceases and the viscosity begins to increase.

This is one of the characteristics of water that allows life on Earth; let's just think of surfaces of frozen water, where the ice is above and below the biological activities in the liquid water are continuing.

Surface tension. Also, this property depends on the intermolecular forces; water is characterized by a very high surface tension. Even this abnormal behavior is at the basis of the existence of life; in fact, surface tension plays a key role in capillary phenomena, such as rising of lymph in blood vessels and water from the soil.

Melting point, boiling point, and specific heat. All three of these points have higher values than you would expect. Generally, the smaller the molecules are and the smaller the boiling point. In theory, the water should boil at $-93^{\circ} \mathrm{C}$ and solidify at a temperature of only a few degrees below. Fortunately for living beings is not so.

Moreover, the specific heat of a solid is generally greater than that of the same liquid substance. Instead, when water gels, its specific heat drops to a value equal to half that of liquid water, therefore, by supplying energy to liquid water, only half of this energy is spent to raise the temperature, the remainder is stored in the mass of the liquid.

This property causes the water to absorb and give heat very slowly, and this peculiarity is also crucial for life on Earth. In fact, living beings are so protected from sudden temperature fluctuations, the oceans absorb solar energy by storing it and forming a huge energy tank, which is gradually released as heat when the warm ocean currents move slowly from the tropical regions towards the cold ones of the poles. All these mechanisms have made possible the development of life on Earth and contribute to maintaining it.

Dielectric constant. The dielectric constant for $20{ }^{\circ} \mathrm{C}$ is very high $(\varepsilon r=80)$ compared to that of ice $(\varepsilon r=5)$. This peculiarity allows the water to have high absorption in the frequency range from microwaves to infrared rays; to be an excellent solvent and also a dissociating agent. In the water, due to the high dielectric constant, there is a loosening of the bonds between the molecules dissolved therein and therefore thermal agitation is sufficient to ionize them; by this way, liquid water is richer in electrolytes, thus enabling all vital processes. Eventually, tissues and organs with high water content are in a state of ionization.

\section{Magnetic properties and the "memory" of water}

We below list a set of properties, on which there is a debate and are not recognized by a great part of academic scientists:

Water flowing in a pipe, sited in the magnetic field generated by the two poles of a magnet acquires some properties:

$>$ no limestone incrustations are formed;

$>$ dissolves the limestone incrustations that may be present;

$>$ its surface tension decreases;

$>$ it has a very pleasant taste, while under normal conditions is a tasteless and odorless liquid

$>$ desalinates salty soils;

$>$ it greatly limits the survival of microorganisms. 
The most controversial property is undoubtedly the magnetic memory of water.

It may be useful to recall a very brief story about the scientific path that preceded that controversy, starting from the pioneering works of Giorgio Piccardi at the end of the Thirties. After studying the precipitation of various substances in water, Piccardi was convinced that different ways of precipitation were due to the action of magnetic fields. By virtue of this action, water becomes "activated" in two different configurations: "T", less viscous than normal water; "R", more viscous, with different precipitation effects [1-3]. Activation modifies also biological properties of water and, in this way, biological processes in living systems [4]. In successive experiments, aimed to avoid the limestone formation in boilers and pipes, Piccardi observed that very weak signals from external environment, mainly from solar fluctuations, were able to induce a change of state in solutions $[5,6]$. In late Fifties Piccardi documented with a series of experiments the action of low frequency electromagnetic fields on water. $\mathrm{He}$ noted that water treated with electromagnetic fields of $10 \mathrm{kHz}$ frequency was activated and showed a clear decrease in surface tension $[7,8]$. It's worth to note that Piccardi was a "precursor" also with the debate that arose at the time about his researches; a full insight of his wide contributions in various scientific sectors can be found, mainly about water, in [9].

In 1988 Jacques Benveniste published, with other researchers, a paper describing the action of very high dilutions of anti-IgE antibody on the degranulation of human basophils [10], findings which seemed to support the concept of homeopathy. Since Benveniste was a recognized immunologist and head of the INSERM Unit 200 (immunology, allergy, and inflammation), the French National Institute of Health and Medical Research, the results of that paper gave rise to an international controversy. A journalist coined the term "water memory" because in the Benveniste's experiment the dilutions of the antibody were so high that no of its molecules remained but only molecules of water. Thus, a conclusion to draw out was that the "activation" of water, operated by anti- $\operatorname{IgE}$ antibody, lingered also in its absence making water biologically active. Time later, in the nineties, after studying further biological effects in presence of a magnetic field [11], Benveniste asserted that this "memory" could be digitized, transmitted, and reinserted into another sample of water, which would then contain the same active qualities as the first sample [12]. Encouraged by the public support of Brian Josephson, a physicist Nobel laureate, Benveniste continued his experiments along the same basic lines, culminating with a paper claiming the effect could be transmitted over phone lines [13]; this was followed by another paper on electronically remote-transmission [14].

Several Physicists (among them, Preparata, Del Giudice, Zhadin, Widom, Srivastava) have elaborated theories about the peculiar structures of water, which are supposed to be capable of retaining information on its conformation in a stable manner. Their model and theories have already been directly presented by one of us, or in any case reported, in "Cosmos and Biosphere" Conferences (see [15-18]).

\section{Water in the cells}

The cell consists mainly of water, as well as the interstitial fluid, the electrolytic solution in direct contact with cells that is responsible for their nourishment and purification. The charges at the two surfaces delimiting the cell membrane are not balanced, thus generating a difference in potential. Within a cell the interaction between mitochondria and microtubules allows the generation of an electromagnetic field that can play a key role in long-range communication and cellular organizational structure.

Starting in the late Sixties and continuing until his death in 1991, Herbert Fröhlich, a famous physicist, developed a theory of biological coherence based on quantum interactions between dipolar constituents of biomolecules, such as those of the enzymes, membranes, organelles and the same cells; a relevant feature of this theory was exactly the special structure supposed for the biologic water (micro-trabecular structure). He thought that endogenous electromagnetic fields exist in all living systems and they are responsible for long-range cell communication [19]. Living systems are open, nonlinear, far from the thermodynamic equilibrium and very highly organized. $\mathrm{He}$ hypothesized on the basis of quantum mechanics that endogenous electromagnetic fields contribute to maintain all these characteristics. The fundamental cell organelles to argue this theory are the mitochondria and microtubules; the latter, filaments that make up the cytoskeleton, are dipolar structures subjected to oscillations and are aligned with mitochondria during the interphase. The static electric field of mitochondria allows the generation of electromagnetic field produced by microtubules, because the latter os- 
cillate. As a result of the hypothesized nonlinear interactions, Frцhlich predicted the generation of coherent modes of excitation, representable as quantum dipole oscillations, in the microwave frequency range [20].

This line of reasoning is homogeneous with that of Del Giudice and Preparata [21, 22] - Del Gudice was a follower of Frцlich - and is at the base of many current hypotheses on the nature and behavior of cellular water, hereafter shortly recalled.

About $90 \%$ of cellular water is present as "bulk water", or as ordinary water. Ordinary water is located in the aqueous compartments of the cell, then in the cytosol, in the nucleus, and within the cytoplasmic organelles. The remaining 10\% perhaps also a greater percentage than that held up to now - is called "bound water" (or primary hydration, primary hydration water, ordered water). Bound water is near the surface of free ions, metabolites, macromolecules and structural components of the cell and shows different properties compared to ordinary water: higher viscosity, decreased thermal motion of molecules and different $\mathrm{pH}$. In the "ordered water" there is a charge separation - let's recall the peculiar properties due to the electronegativity difference between hydrogen and oxygen - and this separation generates layers of coherence domains, explainable with quantum mechanics. The coherence domains are formed around structures with hydrophilic surfaces, including microtubules and mitochondria, and, outside the cell, they can have macroscopic dimensions and properties similar to a gel. In a cell, coherence domains are formed because of electrostatic field of mitochondria and are subjected to electromagnetic fields produced by microtubules. The oscillation frequency induced in coherence domains by an electromagnetic field is lower than the frequency of that field in the vacuum; this event prevents loss by radiation outside the coherence domains. The energy of a molecule in a coherent state is lower than in the incoherent state, and this "energy gap" can be seen as generating a coherent state.

The plausibility of this framework is such that we often refer to it even if we don't know any experimental measure that directly shows the existence of those domains.

The existence of electromagnetic fields generated by cell components - the endogenous electromagnetic fields - has been detected on different living systems (see [23-25]) and their existence can be postulated in all living systems. With endogenous electromagnetic fields could be possible to explain the long-range cell communication that the only chemical communication cannot explain, because chemical communication uses short-range forces generated from chemical bonds.

\section{Biological and clinical implication of water dynamics changes}

Water dynamics changes are relevant in pathophysiological status? The question is actually without a clear answer while the main part of scientific and medical Community thinks and wrote that water dynamics is no stable and is dominated by Brownian motions. Generally, Philip Ball wrote: "Water molecules associate by means of weak chemical bonds called hydrogen bonds. Although in the main they form and break on timescales of about a trillionth of a second, nonetheless they seem to offer a vague possibility that water might form clusters of molecules with specific shapes and behaviors" [26].

The existence of clusters, coherent domains, collective phenomena in the global biological system of humans is somewhat intuitive. Billions of cell work together simultaneously and it couldn't possible without a structure of coordination and a great order inside of human body. If a somewhat mechanistic comparison is allowed, the ferromagnetic materials would not be such if they did not have highly ordered domains inside them, the Weiss regions. We can look at diseases as a factor introducing a certain degree of disorder into the human body, in this sense they cause increase in entropy in biological systems, and in their predominant medium, the water. We can conjecture that a good method to detect a disease, and how it is working, is to refer to the pathway of Chinese meridians, measuring with an electronic device the bioelectric impedance of those points of the skin, that have been individuated by a millenarian experience as a source of information on health. In fact, it is well known and the whole Voll's practice witnesses that Chinese medicine correlates those points of skin with internal organs of human body.

In fact, correspondingly to those points about two thousand and half, of which only few on the hands - the cutaneous resistance is lower than in all other points of the skin, up to one order of magnitude, as it is reported by a lot of experimental data; and one can compare a known datum with the measured value he is obtaining. The first who attempted this way to perform a diagnosis was 
Dr. Reinhold Voll with his EAV (Electro Acupuncture of Voll), in the Fifties. EAV is a diagnosis method still worldwide applied, with a not negligible presence in scientific literature (see, for instance, [27-30]), even though the reliability of the obtained diagnosis strongly depends on cleverness of physician, his knowledge of Chinese medicine and of the Voll's "diseases atlas".

Over last sixty years, Voll and many other scientists hypothesized that human body could be seen as an electrical system, endowed with electric circuitry, and that the values of the Skin Electric Parameters (SEP) could be connected with the health status performance and pathophysiological processes, as inflammations, pain, allergy, gastrointestinal function, etc. General measurements on meridians have highlighted in subjects, mainly affected by meteoropathies but also by other pathologies, that the electrical resistance was averagely increasing up to 43 Scale Units (SU) of SEP, corresponding to $130,000 \Omega[31,32]$.

In a first interpretation proposed by Reinhold Voll the "normal" value of the measurement was set to $50 \mathrm{SU}$, corresponding to $95,000 \mathrm{Ohm}$. This level was presented as an equilibrium value for human health, so that many efforts by doctors using EAV were devoted obtaining this goal. After the administration of a coherent therapy, we registered an average decrease in resistance at $39,000 \Omega(70 \mathrm{SU})$; on the contrary, in many chronic diseases an average increase of resistance to $130,000 \mathrm{Ohm}$ (43 SU) was measured; and in cancers, as well as in other

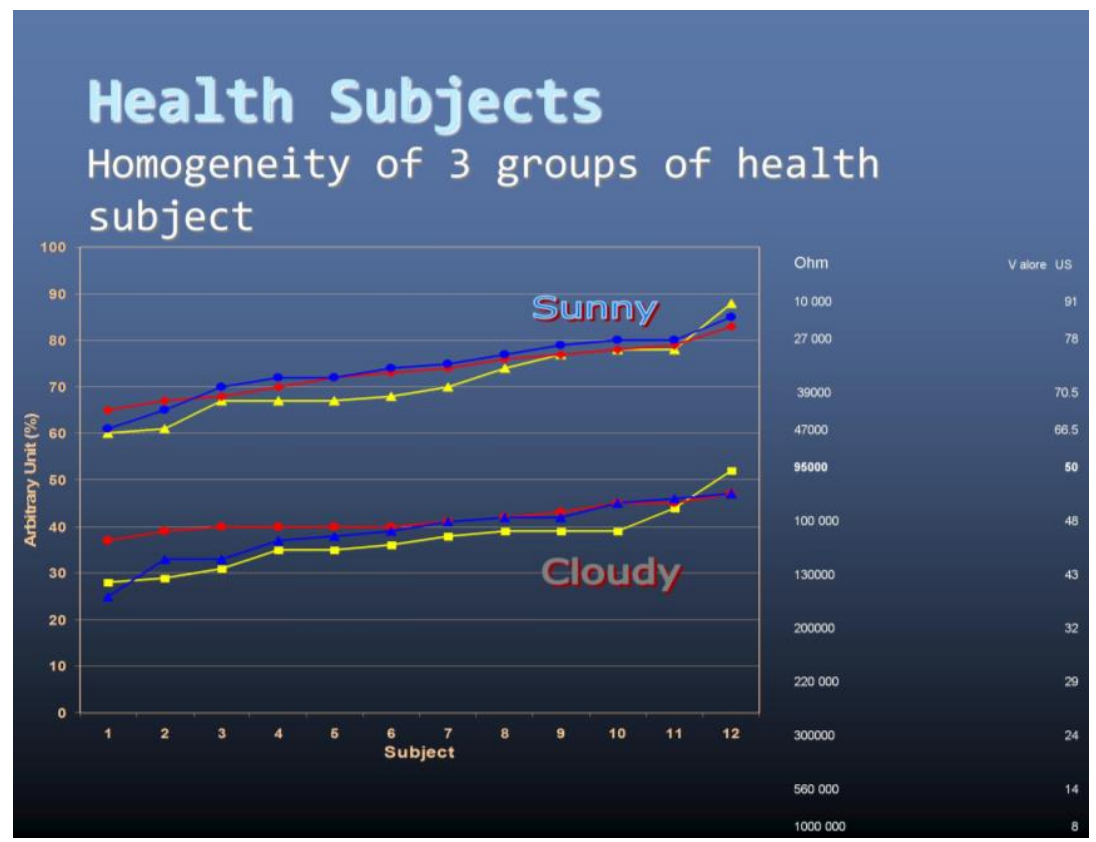

Figure 2: SEP variations under influence of weather conditions critical disorders, we observed an increase of resistance up to $250,000 \mathrm{Ohm} \mathrm{[33].}$

Another experiment, always following the EAV procedure, has been performed with twelve "homogeneous" subjects, i.e., all in a "normality" range of health state, meteosensitivity but not meteoropathic, none younger than fifty years (it was the personnel of a clinic). Each of these persons was individually subjected to three measures in sunny weather and three measures in cloudy weather; all the obtained values for the two weather conditions were reported in a table, ordered following a non decreasing trend, that is, at the first places $(1,2)$ persons with the smaller values of SU, in the second places $(3, \ldots, 8)$ those with greater SU values and so on. The three groups of measures for each of the two weather conditions, represented by dotted lines blue, red and yellow, exhibited an interesting homogeneity of behavior [34] (see Fig. 2).

In Fig. 2, in abscisses is reported the number of the volunteers that were submitted to the measures (from 1 up to 12 persons). In ordinates is represented the Scale Units, from 0 to 100 , that are correlated to the resistance in $\mathrm{Ohm}$ (on the right of the table).

In this context a fundamental step was, in 1988, the approval in Moscow by the Minister of Health of the Voll System for studying and monitoring of Elio-biological interaction [35].

Nevertheless, after 20 years of experiences in diagnostic and therapeutic use of EAV we came to the conviction that the resistance measure has a dynamical character and the objective of therapy driven by the SEP be not the "normal" level of $50 \mathrm{SU}$, but the increase of conductivity of the skin in correspondence to the Chinese meridians (let's remind the correlation among those points and organs of human body). Increasing of conductivity in human bioelectrical system, an objective that can be achieved by means of many therapeutic tools as drugs (all kind), magnetotherapy, SPA therapy, climatotherapy etc., turned out in a success factor in many therapies.

Trying to find an explanation of those successes, many efforts have been devoted by some Italian researchers (Avino, Gigante, Grimaldi, Marinelli, Valenzi) that per- 
formed over the time several experiments, only for few of which it has been reached, in the assessment of those researchers, the status worthy of a scientific referee. The latter papers will be mentioned after; immediately here, we will recall some of those results, but recurring to a simplified scheme, to be taken as a linear approximation of the more complex electric circuitry that underlies the models that explain how it works electroacupuncture of Voll, characterized by the nonlinearity of skin response to solicitation.

In this linear approximation, aimed at not to burden understanding with technicality, it is possible to give a role to a very simple but fundamental law of electricity, the Ohm's law, that linearly links the physical quantities in the simplest of electric circuits:

$$
V=i \cdot R,
$$

where $V$ is the difference of potential (or tension) at the ends of a conductor; $R$ is a characteristic of the material the conductor is made of, the resistance, and $i$ is the current intensity that flows in the conductor by virtue of the applied $V$. In the cases where one measures a significant decrease of $R$ between two points of the skin, Ohm's law shows that, correspondingly, the current intensity $i$ has increased, where $V$ is the tension applied to those two points, like is usual when EAV measurements, for a small value of the stimulating tension $V$, are performed. To a greater current intensity corresponds a greater value of bioelectric power $W$, that, in this simplified scheme, is given by

$$
W=V \cdot i
$$

and just looking at the influence of the sun radiation intensity, i.e., the electromagnetic power density through a surface unit orthogonal to the rays of the sun, on the values of SEP such as that are determined by EAV, it seems reasonable hypothesizing that the correlation with the increase of current $i$ and, consequently, of bioelectrical power $\mathrm{W}$ provides electrophysiological parameters fundamental in the regulation of human body. On the other hand, bioelectric power in the body districts, measurable with muscular test by a dynamometer $(0-100 \mathrm{Kg})$, vary with functional correlations (performance status, immunological status, muscle power, pain, inflammation, allergy, dyspnea, etc.), signaling better performance at the increase of bioelectric power.

Today we prefer to speak of impedance, because a pure resistance is one of the limit concepts we find in Physics; in fact, also at extremely low frequencies (less than ten Hertz) there is always a capacitive component that, together with a resistance, gives rise to electric impedance.

Good news about electro-cutaneous parameters is that we can now use a device of advanced electronics, APEC 300, with a very higher resolving power than Voll's apparatus; further, it can be used for acupuncture with the usual punctiform electrodes, as well as in other applications different from acupuncture, performed with ordinary electrodes. In this latter way one partially loses the completeness of information linked to acupuncture in Chinese points, but gains in the reliability of diagnosis when one is not expert in Chinese medicine.

Moreover, this device allows directly measure the skin potential as a function of time, a parameter strangely forgotten in many scientific reports that, instead, is very rich of information about health status. By virtue of a software installed inside the device, it can be immediately provided an analysis in frequency - the spectrum associated to the skin potential curve - that, in the region of ]0.1] Hz, gives a so called "electromagnetic footprint" that we are conjecturing could characterize the health status of each body district submitted to the measure. This kind of measure is a mere registration of signals emitted by our body, like an ECG or EEG, and not a response to an electric stimulation, as happens in all measurements of impedance, with applications obviously easier than those measures that request specific approval or protocol.

The existence of bioelectric parameters measurable on the skin can suggest that an electromagnetic (e.m.) mechanism could underlie the so called pseudo-allergies to drug, food etc.: since these symptoms are the effects of drug, the possibility arises that the molecules of drugs could involve an e.m. action apart from the well know chemical action; and the molecular signaling, registered by means of SEP measurements, performed comparing without/with drug cases, could play an interesting role in biological processes and in therapy. Hence, the paradigm: It's the dose that makes the drug, may not be universal.

In the graphs of Fig. 3 in the ordinates is represented the value of SU and in abscisses the time of exposition of the patient to drug. In the experiment were tested 8 drugs against pain and inflammation: nimesulide, diclofenac, ibuprofen piroxicam, naprossene, indometacine, COX2, and cortison. Only one (Nimesulide) was able to improve clinical condition, in particular reduction of pain. To this 
improvement was correlated a special behavior of SEP, as can be easily seen by comparing the two graphs of Fig. 3 [36]. This kind of comparison could be used for the choice of FANS, gastroprotector, antistaminic etc., on the basis of the molecular signaling of drug on SEP, and can be detected as a strong variation of resistance that, following Voll, bioelectrically modulates health status.

Fig. 3 is worthy of a particular remark: the graph on the right has been obtained not as a result of ingestion, but simply posing the chosen drug outside the body, even though at a small distance $(1.5 \mathrm{~cm})$. How is it possible a kind of drug action that is not an exaggeration to define as an "action at distance"? An analysis of this fact implies a lot of caution, it was the hitch that obliged Einstein to a complete reformulation of classical Physics, that led to the field equations of General Relativity. Among other important things, the latter theory gives the right answer to why Earth goes around the Sun; in fact, this astronomical motion cannot be explained in terms of Newton's universal gravitation law precisely because this kind of immediate action, at distance, should have an infinite velocity in contrast with the postulate of light velocity as unsurpassed limit for any physical action. Thinking about it, the nimesulide of our experiment is sited at a distance like that of Earth-Sun, with respect to the scale of the cells on which it acts.

In the case of electromagnetic interactions, that undergo for what the electrostatic action is concerned the same criticism of Einstein versus gravitation law, there is another function, besides

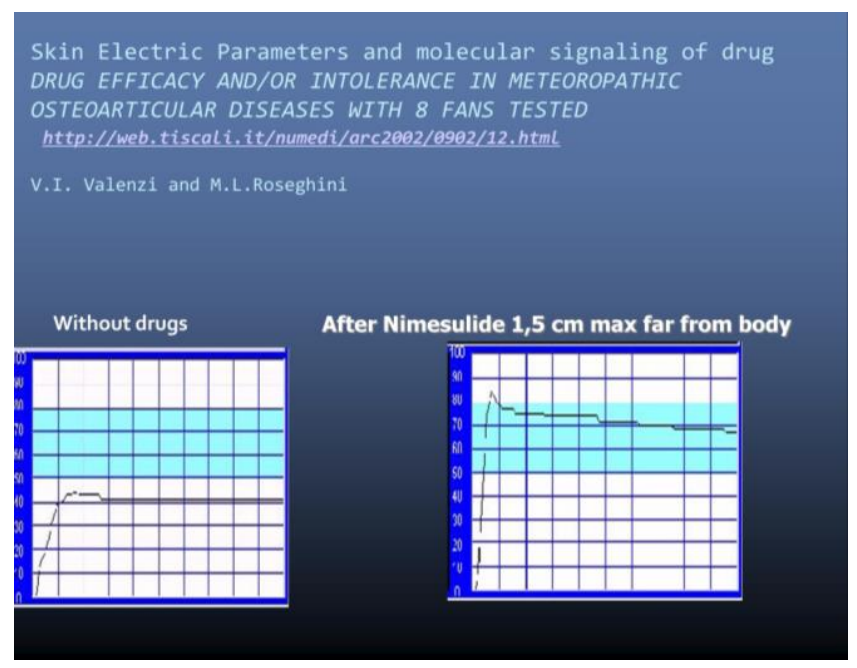

Figure 3: SEP variation in time due to molecular signaling of drug electric field $\mathbf{E}$ and magnetic field $\mathbf{H}$ : the vector potential A, not directly observable and characterizing the wave propagation of electromagnetic fields. Many theoretical Physicists - Bohm, Aharonov, Josephson, Puthoff, Preparata, Trukan, Widom, Srivastava, and others - have assigned to A a key role in action at distance, not in contradiction with General Relativity; and that bacterial DNA sequences can produce electromagnetic signals [15] is another experimental example of an action at distance supported by electromagnetic fields. It is an intriguing possibility, we are working on it, that the vector potential $\mathbf{A}$ be the "director" of non chemical drug action at distance; it could theoretically explain many problems, like that represented in Fig. 3, that occur in medical practice.

All this reasoning underlines that we are in a kind of "excess" of theory and models with respect to available experimental data. It is one of our goals to begin balancing this situation, that could provoke some justified criticism, with a program of experimental measurements, some of whose are briefly sketched in the following section.

Another line of research to understand how some drug signals from water or directly by drug or food (without chemical interactions) could be able to induce change in cells is to investigate if some of those effects can be interpreted in terms of quantum coherence interactions (see sect. 3), whose behavior is represented in the following Fig. 4, just to mention it. The context of this research approach is the so-called quantum chemistry, in which we are trying to move a few steps.

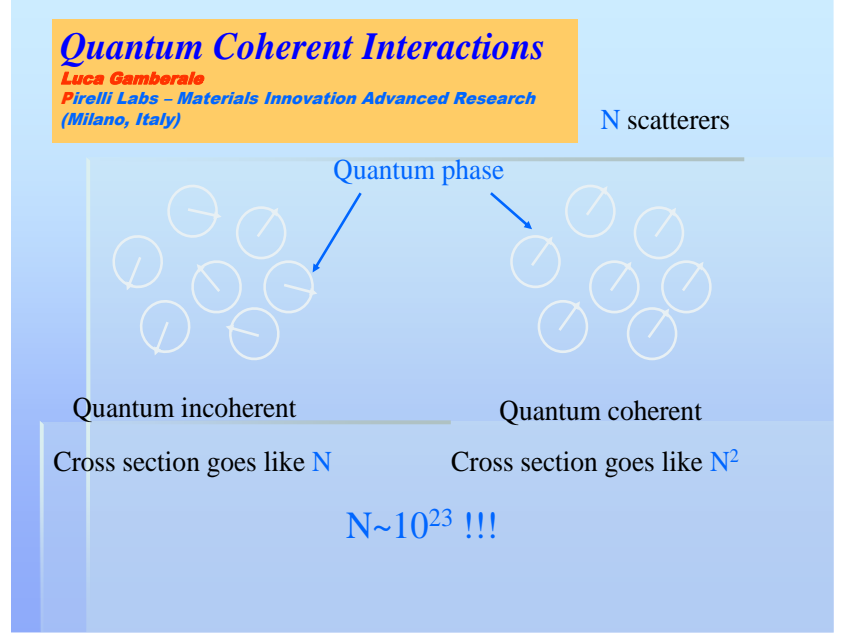

Figure 4: Different behavior between two groups of coherent and incoherent 
This development could play a real role in our understanding of the critical problem of side effects of drug (more than 100,000 Americans die every year [37]), and orient medical practice approach to driven therapy by quantum chemistry in order to improve risk benefit ratio in pharmacotherapy.

\section{Conclusions}

A two-fold possibility of research is open ahead of us: clinical tests, "water tests". Let's sketch a draft.

In both cases we mainly resort to APEC 300 (see sec. 4), designed in the Bio-electromagnetism section of CIRPS and mainly aimed to measure electro-cutaneous (EC) parameters. This device is equipped with a high resolving power, able to record the smallest variations of the measured values and, then, of the investigated properties. It can also perform a measure seldom treated in literature, the potential, and we like to recall that to each measure of this kind one can associate a frequency spectrum, that is a Fourier analysis of the potential, by virtue of internal software of the device. Measures realized in the phase of calibrating and testing APEC 300 have persuaded us that the frequency spectrum of potential could represent, probably in the $] 0-0.1] \mathrm{Hz}$ region, an electromagnetic "footprint" characterizing each type of living object under measure (human body, body districts or systems, fruits, leaves of plants, cells, etc.).

About the first line of research we underline that APEC 300, in its actual configuration, can be used by doctors not only for EAV, with more reliable results than the traditional ones such as those reported in references, but also to perform precocious diagnoses through the applications of ordinary electrodes to the skin areas sensible to detect: gastrointestinal diseases [38], premonitory signals of breast cancers [39] or female genital disturbs [40]. Further experimental measures could confirm these results and extend EC analysis to other pathologies. These researches need of a collaboration with clinical structures and doctors interested and willing to perform such kind of experiments. Thus, we are not able, now, to schedule time and steps of research.

Another kind of clinical application is to measure the quantity and the characteristics of the overall water contained in the body, as it is possible to do by APEC 300, as a test of health status; and to remark the variations of body water under the assumption of a specific drug. This test has, probably, not to be submitted to medical approvals or bioethics committee and we are expecting some address by clinicians to convert spot measures on consenting subjects in a possible research program.

The second line of research, the "water tests", can be in turn subdivided into two issues:

An extremely weak "field" can act on an organic or biological system? This is a recurring problem in scientific researches and is the case of mentioning again Giorgio Piccardi, because he was afraid that many his experiments on the activation of water could be altered by "fluctuations" due to the different velocity of Earth in the different seasons, the variations of the solar magnetic activity, the "atmospheric potential" changing during the experiment. A witness of this concern is the subject of the last paper he wrote with Carmen CapelBoute [41].

The posed question has positive and measurable answer from a stock of natural phenomena, where a solicitation of very low intensity is at the base of a response: the electroreception in elasmobranchs is activated by $1 \mu \mathrm{V}$; the human eye retina is capable of detecting few photons; a very low concentration from $10^{-10} \mathrm{M}$ to $10^{-12} \mathrm{M}$ of the aldosterone or anti-diuretic hormones is capable of saving the sodium request of the renal tubules in our body, and, not physiological, the Zhadin effect [42].

In the last twenty years, much attention has been devoted to the behavior of aqueous solutions of cells, enzymes or more simple organic compounds, when are solicited by an extremely weak magnetic alternating field, mainly in the ELF region. Our idea is to test biological or organic aqueous solutions at a very low level of concentration, measuring their electric properties like potential and impedance, not only when submitted to an external magnetic field; better, under the influence of a specific drug at a very Iow concentration.

To this aim, we remember that the potential and impedance measures by APEC 300 maintain a rigorous sense also when not applied to the EC parameters, as, i.e., in the case of cell cultures or aqueous solutions; besides the device has an operational range that allows analyzing the micro variations of potential or impedance. A comparison between a not exposed cell culture with the treated one with a specific pharmaceutical at a very low concentration is achievable, almost immediately, in terms of the change of color of the culture through a gamma extending to the color of the cell apoptosis. Experimental mea- 
sures can individuate the threshold value, if any, below which there is no difference between the two cases. The further step is to detect the impedance response of a patient who has been given that drug at that concentration level, to be compared with the same response in absence of the drug assumption.

This kind of research postulates a partnership among bio-physicists and clinicians.

"Water memory". Benveniste's biology experiments have suggested the existence of molecularlike effects without molecules ("memory of water") [10], [11]. On the same line of reasoning Luc Montagnier, in collaboration with other authors, proposes that "nanostructures" from viral or bacterial DNA are able to produce, in high aqueous dilutions, electromagnetic signals (EMS) emitting in a ULF region $(500-3000 \mathrm{~Hz})$; essential to this occurrence is an electromagnetic stimulation by a natural field at one of the Schuman's frequencies (starting from $7.8 \mathrm{~Hz}$ ) or also by an artificial field at $50-60 \mathrm{~Hz}$. The authors assert that the need for such stimulation witnesses a resonance phenomenon and a theoretical explanation of EMS is possible by resorting to the quantum field theory [43], [44]. Another experiment, led by Livio Giuliani, seems to confirm, at a first step, the Montagnier's results, thus supporting a new diagnostic perspective to the development of highly sensitive detection system for chronic bacterial infections in human and animal diseases, since in the genomic DNA of most pathogenic bacteria are contained sequences which are able to generate such EMS [45]. In a subsequent paper, it has been shown that the recorded EMS and nanostructures induced in water carry the DNA, by retrieval of that same DNA by classical biochemical amplification methods. Moreover, such a transduction process has also been observed in living human cells exposed to EMS irradiation [46].

These and other similar experiments recall the difficulties and specific conditions, encountered or to be satisfied, for electrochemical measurements of water and aqueous solutions. Over the last decades measures on $\mathrm{pH}, \mathrm{DC} / \mathrm{AC}$ conductivity, impedance spectroscopy have been realized for characterizing effects of "weak emissions". A particular attention has been given to EIS devices that are apparatuses able to measure conductivity and impedance spectroscopy (see [47-49]). We can remark, softly, that these latter measurements are not only complex but also that they need a lot of caution to avoid interferences of device on the specimen under measure; for instance, measurement on conductivity can drastically alter the characteristics of aqueous solutions, in such a way that hits the reliability of experimental results. Moreover, EIS "philosophy" doesn't take in account a significant parameter, the potential, on whose measure can base reliable comparisons between stimulated and not stimulated aqueous solutions.

Thus, it appears to us useful to integrate the experiments on water and aqueous solutions by directly measuring their potential and analyzing the corresponding frequency spectrum. Despite its high resolving power, APEC 300 is relatively easy to be used; measurements of potential are almost not interfering with the object under measure because are not a response to a stimulation but a detection of an endogenous property, and external noise can be downsized to a very low and quantifiable level; in fact, the device is able, in this kind of application, to distinguish noise variations of $10 \mathrm{nV}(1 \mathrm{nV}=$ $=10^{-9} \mathrm{~V}$ ), that is the same level of accuracy, or better, of other measure procedures, but much more at the hand.

Starting from a primordial question - what is the method for a physical, quantitative detection of a difference, if any and in an easy verifiable manner, between water and water that has been stimulated - we have carried out a first set of measurements of potential of tap water and treated tap water by an alternating magnetic field at $50 \mathrm{~Hz}$ and $126.10 \mu \mathrm{T}$ peak intensity. The comparison between the frequency spectrum for the two cases exhibits a high reduction of the maxima of potential for the magnetized water, as one can see in the figures of the Annex, where, besides, the other experimental parameters are given.

One datum can well express the difference between the two cases: in the region ]0-0.3] Hz, the mean value of the potential is $0,207 \pm 0,015 \mathrm{mV}$ for tap water while is $0.035 \pm 0.003 \mathrm{mV}$ for magnetized tap water. Beyond $0.40-0.45 \mathrm{~Hz}$ frequency, and up to $30 \mathrm{~Hz}$, the values of the potential are very small, of the same order of the errors.

The special relevance of a so tight and ultralow band of frequency is not so astonishing if, for instance, we look at most experiments of Heart Rate Variability (HRV), since they take place in the same frequency band.

\section{Acknowledgments}

This experimental project can be realized by the BEM Section of CIRPS in its laboratory and we hope to report some first results in next months. 


\section{References}

[1] Piccardi G. Sopra un nuovo fenomeno di natura elettrica e sopra un nuovo effetto presentato dai metalli. Gazzetta Chimica Italiana. 1938;68:246-63.

[2] Piccardi G, Corsi ML. Sulla precipitazione del carbonato di calcio da acqua dura attivata ("T" od "R") e normale. Gazzetta Chimica Italiana. 1938;68(5):287-91.

[3] Piccardi G, Fabrini E, Corsi ML. Sulla tensione superficiale dell'acqua attivata "T". Gazzetta Chimica Italiana. 1938;68(8):471-73.

[4] Piccardi G. Nuovi effetti chimici e biologici dell'acqua attivata "T" ed "R". La Chimica e l'Industria. 1939;7:455-7.

[5] Piccardi G. Sulla disincrostazione fisica delle caldaie e su di una relazione fra fenomeni ambientali ed alcuni fenomeni chimico fisici. Tecnica Italiana. 1951 Sett./Ott;5.

[6] Piccardi G, Capel Boute C. Sui rapporti fra fenomeni ambientali e fenomeni chimico-fisici: primi risultati delle esperienze condotte a Bruxelles. Geofisica e Meteorologia. 1953;1(4-5).

[7] Piccardi G, Cini R. Azione di un campo elettromagnetico della frequenza di $10 \mathrm{KHz}$ sul test chimico: il problema dell'influsso degli atmosferici. Geofisica e Meteorologia. 1956;4(1-2).

[8] Piccardi G. Sulla struttura dell'acqua e sull'influsso di campi elettromagnetici di bassa frequenza. La Ricerca Scientifica. 1959;29(6).

[9] Manzelli P, Masini G, Costa MG. I Segreti dell'Acqua. L'opera scientifica di Giorgio Piccardi. 2nd ed. Roma: Di Renzo; 2012.

[10] Davenas E, Beauvais F, Amara J, Oberbaum M, Robinzon B, Miadonna A, et al. Human basophil degranulation triggered by very dilute antiserum against IgE. Nature. 1988;333(6176):816-8. DOI: 10.1038/333816a0

[11] Benveniste J. Further biological effects induced by ultra high dilutions. inhibition by a magnetic field. In: Endler P C, Schulte J, editors. Ultra high dilution. Kluwe Academic Publishers; 1994. p. 35-8. DOI: 10.1007/978-94-015-8342-8_5

[12] Benveniste J, Aïssa J, Jurgens P, Hsueh W. Digital biology: Specificity of the digitized molecular signal. FASEB Journal. 1998;12:A412.

[13] Benveniste J, Jurgens P, Hsueh W, Aïssa J. Transatlantic transfer of digitized antigen signal by telephone link. J Allergy Clin Immunol. $1997 \mathrm{Feb}$;99:S175.

[14] Benveniste J, Thomas Y, Schiff M, Belkadi L, Jurgens P, Kahhak L. Activation of human neutrophils by electronically transmitted phorbol-myristate acetate. FASEB Journal. 2000;13(1):33-9. DOI: 10.1054/mehy.1999.0891

[15] Arani R, Bono I, Del Giudice E, Preparata G. Qed coherence and the thermodynamics of water. Int J Modern Phys B. 1995;09:1813. DOI: 10.1142/S0217979295000744

[16] Del Giudice E, Preparata G, Fleischmann M. QED coherence and electrolyte solutions. J Electroanalyt Chem. 2000;482(2):110-6. DOI: 10.1016/S0022-0728(00)00019-X

[17] Widom A, Srivastava Y, Valenzi V. The biophysical basis of water memory. Int J Quantum Chem [Internet]. 2009 May 19 [cited 2018 May 22]. Available from: http://jacques-benveniste.org/bio_conf_widom.pdf

[18] Valenzi VI, Widom A, Swain J, Sivasubramanian S, Srivastava YN. Biological Aharonov-Bohm effects and electromagnetic communication signals from bacterial DNA. In: Proc X Int Conf "Cosmos and Biosphere" [Internet]; 2013 Sept. 23-28; Koktebel, Crimea, Ukraine. Available from: http://www.biophys.ru/archive/crimea-2013.pdf

[19] Fröhlich H. Long range coherence and energy storage in biological systems. Int J Quantum Chem. 1968;2:641-9. DOI: $10.1002 /$ qua. 560020505

[20] Fröhlich H. Evidence for coherent excitation in biological system. Int J Quantum Chem. 1983;23:1589-95. DOI: $10.1002 /$ qua. 560230440

[21] Bonifacio R, Preparata G. Coherent spontaneous emission. Phys. Rev A. 1970;2(336). DOI: 10.1103/PhysRevA.2.336

[22] Del Giudice E, Preparata G, Vitiello G. Water as a free electric dipole laser. Phys. Rev Lett. 1988;61(9):1085-8. DOI: 10.1103/PhysRevLett.61.1085

[23] Cifra M, Pokorny J, Havelka D, Cucera M A. Electric field generated by axial longitudinal vibration modes of microtubule. Biosystems. 2010;100(2):122-31. DOI: 10.1016/j.biosystems.2010.02.007

[24] Cifra M. Electrodynamic eigenmodes in cellular morphology. Biosystems. 2012;109(3):356. DOI: 10.1016/j.biosystems.2012.06.003

[25] Pokorný Jiři, Pokorný Jan, Kobilková J. Postulates on electromagnetic activity in biological systems and cancer. Integr Biol (Camb). 2013;5(12):1439-46. DOI: 10.1039/c3ib40166a

[26] Ball P. Here lies one whose name was writ in water. Nature [Internet]. 2007 Aug 8. Available from: https://www.nature.com/news/2007/070806/full/news070806-6.html DOI: 10.1038/news070806-6.2007 
[27] Leonhardt H. Fundamentals of electroacupuncture according to Voll. Uelzen: Medizinisch Literarische Verlagesellschaft $\mathrm{MBH} ; 1980$.

[28] Casimiro L, Barsnley L, Brosseau L, Milne S, Welch V, Tugwell P, et al. Acupuncture and electroacupuncture for the treatment of rheumatoid arthritis. Cochrane Database Syst. Rev. 2005 Oct 19;4. DOI: 10.1002/14651858.CD003788.pub2

[29] Quispe-Cabanilas JG, Damasceno A, von Glehn F, Brandão CO, Damasceno BP, Silveira WD, et al. Impact of electroacupuncture on quality of life for patients with relapsing-remitting multiple sclerosis under treatment with immunomodulators: A randomized study. BMC Complement Altern Med. 2012 Nov 5;12:209. DOI: 10.1186/1472-6882-12-209

[30] Silvério-Lopes S. Analgesia por acupuntura. Curitiba: Institute Brasileiro de Therapias e Ensimo; 2013. DOI: 10.7436/2013.anac.0

[31] Valenzi VI, Grieco U, Garcia A, Marinelli F, Lozito A, Messina B. Cutaneous electrical phenomena in the evaluation of the curative properties of sand and marine environment: Preliminary observation. C.I.R.M. Researches. 1999;3/1.

[32] Valenzi VI, Monaco G, Spada S, Cimaglia P, Petraccia L, Messina B. Ruolo dei SEP (Skin electric Parameters) nello studio delle meteoropatie. Annali di Medicina Interna, 2003;18:164.

[33] Pisani A, Valenzi VI, Lucchetta MC, Grassi M, Serio A, Avino P, et al. SEP variations on subjects with chronic constipation in idropinic treatment. In: Proc VII Int Conf "Cosmos and biosphere"; 2007 Oct. 1-6; Sudak, Ukraine.

[34] Spada S, Lopalco M, Quartieri G, Cimaglia P, Lucchetta MC, Campanella J, et al. Valutazione bioelettrica delle meteoropatie con i SEP (Skin Electric Parameters) [Internet]. 2004. Available from: http://www.cifafondation.org/CIFA_News/ CIFA_News_45.pdf

[35] Valenzi V. L'asse sardo-siberiano per vincere il tempohttp [Internet]. 2017 Apr 24. Available from: https://www.vglobale.it/2017/04/24/1-asse-sardo-siberiano-per-vincere-il-tempo/

[36] Valenzi VI, Roseghini ML. From drug intolerance to a SEP (Skin Electric Parameters) driven therapy. Some preliminar observation. Rivista di Biologia/Biology Forum. 2000;93:306-12.

[37] Lazarou J, Pomeranz BH, Corey PN. Incidence of adverse drug reactions in hospitalized patients: a meta-analysis of prospective studies. JAMA. 1998;279(15):1200-5.

[38] Smalwood RH, Brown BH. Non-invasive assessment of gastric activity. In: Rolfe P, editor. Non-invasive physiological measurements. Vol. 2. New York: Academic Press; 1983. P. 179-217.

[39] Sacchini V. Electropotentials in the clinical assessment of neoplasia. The Breast. 1996;5:282-86. DOI: 10.1016/S09609776(96)90027-2

[40] Itsekson A, Shepshelovich D, Kanevsky A, Seidman DS. Measurement of electrical resistance of dermal-visceral zones as a diagnostic tool for gynecologic disorders. IMAJ. 2010;12:334-7.

[41] Piccardi G, Capel-Boute C. The 22-year solar cycle and chemical tests. J Interdiscip Cycle Res. 1972;3(3-4):413-7. DOI: $10.1080 / 09291017209359357$

[42] Novikov VV, Zhadin MN. Combined action of weak constant and variable low-frequency magnetic fields on ionic currents in aqueous solutions of amino acid. Biophysics. 1994;39:41-5.

[43] Montagnier L, Aïssa J, Ferris S, Montagnier JL, Lavallée C. Electromagnetic Signals Are Produced by Aqueous Nanostructures Derived from Bacterial DNA. Interdiscip Sci. 2009 Jun;1(2):81-90. DOI: 10.1007/s12539-009-0036-7

[44] Montagnier L, Aïssa J, Del Giudice E, Lavallée C, Tedeschi A, Vitiello G. DNA waves and water. JoP Conf Ser. 2011;306(1):1-11. DOI: 10.1088/1742-6596/306/1/012007

[45] Giuliani L, D'Emilia E, Ledda M, Grimaldi S, Lisi A. New perspectives of Bioelectromagnetics in Biology and Medicine: DNA Spectra for diagnostic purposes. JoP Conf Ser. 2011;329:1-10. DOI: 10.1088/1742-6596/329/1/012011

[46] Montagnier L, Del Giudice E, Aïssa J, Lavallée C, Vitiello G. Transduction of DNA information through water and electromagnetic waves. Electromagn Biol Med. 2015;34(2):106-12. DOI: 10.3109/15368378.2015.1036072

[47] Kernbach S, Kernbach O. Reliable detection of weak emissions by EIS approach. Int J Unconvent Sci. 2016;E1:90-103.

[48] Kernbach S. High-resolution electrochemical measurements for detecting effects of non-chemical treatment of water. In: Proc Conf Physics, Chemistry and Biology of Water; 2017 Oct 28; Sofia, Bulgaria.

[49] Kernbach S, Kuksin I, Kernbach O. On accurate differential measurements with electrochemical impedance spectroscopy [Internet]. 2016 May 14. Available: arXiv:1607.07292 v1.[physics.ins-del] 


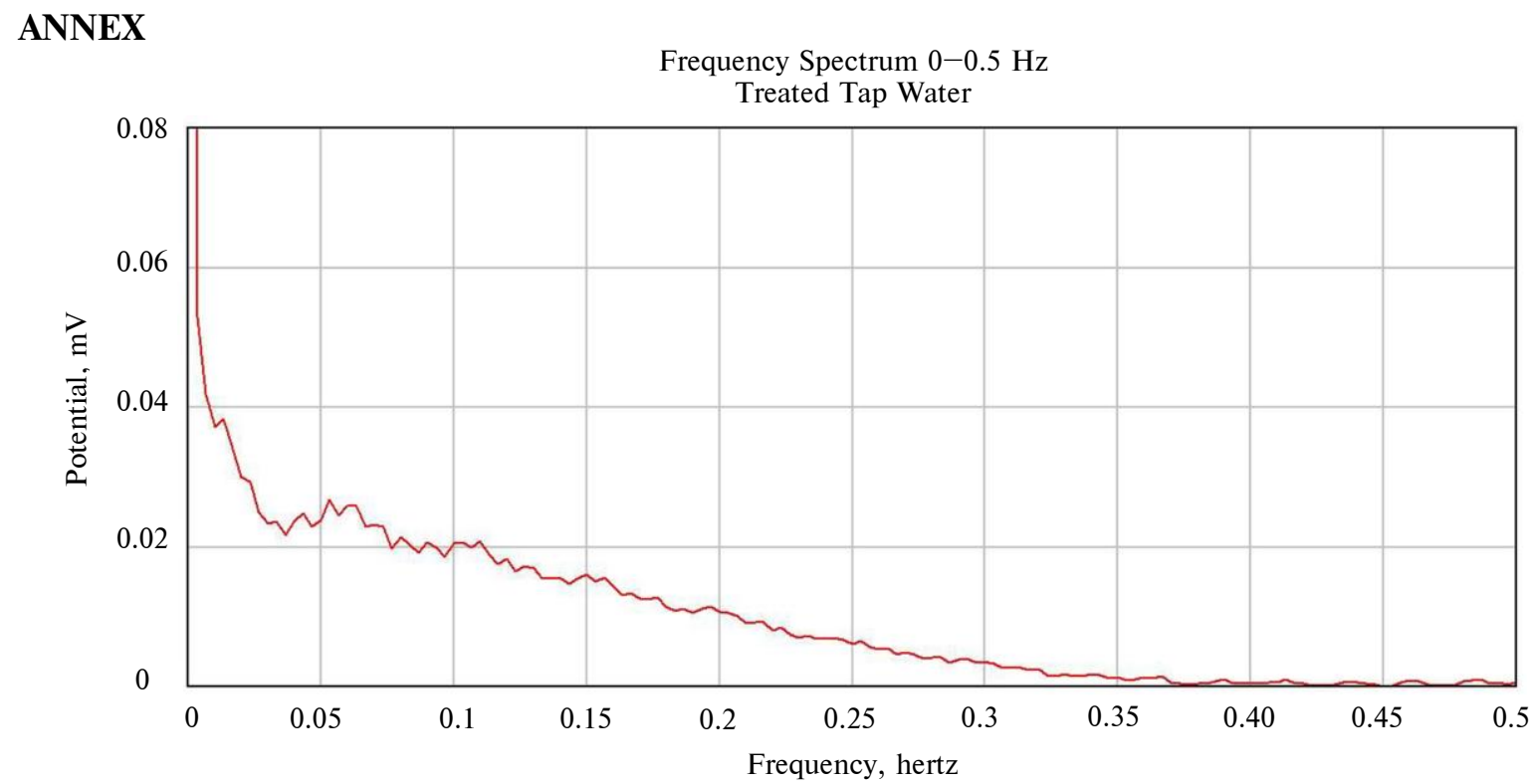

Fig. I

Frequency Spectrum $0-0.5 \mathrm{~Hz}$

Treated Tap Water

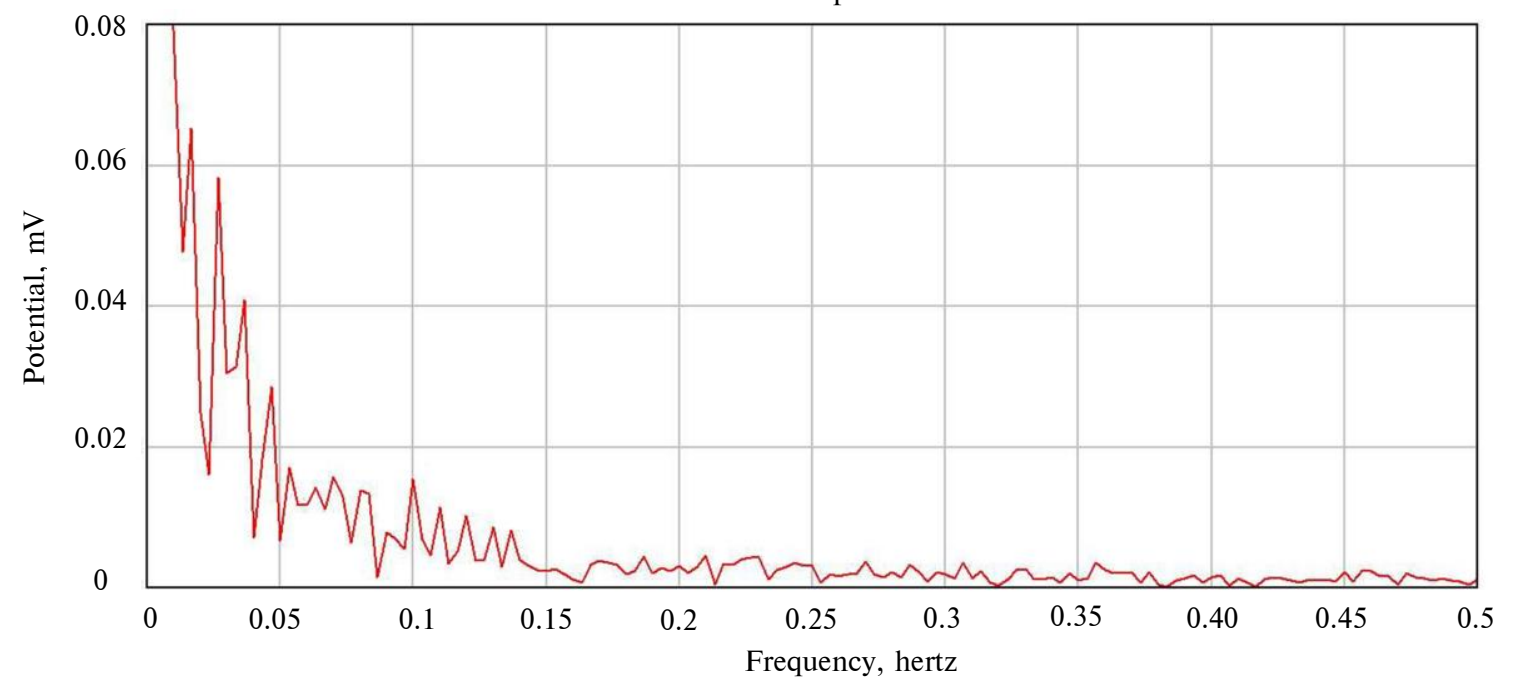

Fig. II

Five measures for each case have been performed and all measures have been realized in a "climatized" room able to maintain constant temperature and humidity; room magnetic field was less than $0,03 \mu \mathrm{T}$. The exposure time in order to magnetize water was 15 minutes for each measure and the peak value for the alternating magnetic field at $50 \mathrm{~Hz}$ was $126.10 \mu \mathrm{T}$. Water was contained in special small trays electrically connected, suitable also for experiments with aqueous solutions of drugs or cell cultures. Fig. I and Fig. II are representative of the five spectra obtained respectively for the two cases, and give at glance the reduction of potential for magnetized water (the scale of potential in Fig. II is one tenth of that of Fig. I); to better quantify this diminishing, the spectrum integral curve has been calculated to obtain the mean value of the potential. The values reported in the article, respectively $0.207 \mathrm{mV}$ and $0.035 \mathrm{mV}$, are the mean value among the five values obtained for each case. Due to the limited number of events, the error has been calculated as the maximum semidispersion, respectively $0.015 \mathrm{mV}$ and $0.003 \mathrm{mV}$. In Fig. II, the difference between the values of potential at $0.2 \mathrm{~Hz}$ and at $0.25 \mathrm{~Hz}$ is about $60 \mathrm{nV}$. 


\section{ДЕЯКІ СПОСТЕРЕЖЕННЯ ЩОДО РОЛІ СТАНІВ ВОДИ У БІОЛОГІЧНИХ І ТЕРАПЕВТИЧНИХ ЕФЕКТАХ}

Виявлені особливі властивості води, в тому числі “пам'ять води", акцентують увагу на поведінці води в клітині, “упорядкована" структура якої, ймовірно, обумовлена ендогенними електромагнітними полями, що генеруються органелами всередині клітин, такими як мітохондрії та мікротрубочки. Повідомляється про біологічні та клінічні наслідки динамічних змін води, головним чином на основі аналізу SEP (Skin Electric Parameters), і висувається гіпотеза про "дію на відстані", яка чиниться препаратами низької концентрації. Нині для вимірювання електрошкірних параметрів у нашому дослідженні може бути використаний пристрій сучасної електроніки APEC 300, який поряд з електроакупунктурою за Фоллем, але з точними кількісними значеннями, може виявляти мікрозміни параметрів водних розчинів клітини, а також води, коли аналізований об'єкт зазнає впливу зовнішнього електромагнітного слабкого поля, так само як і препарату за дуже низької концентрації. У висновках пропонується проект двох можливих напрямів досліджень, один із яких залежить тільки від нас самих і від "випробувань води" в контексті експериментів із “пам'яттю води”. Поряд з експериментами CEI щодо провідності та імпедансної спектроскопії, у роботі з використанням АРЕC 300 пропонуються дуже високочутливі вимірювання важливого параметра - потенціалу; свого роду вимірювання, менш складні та більш надійні щодо перешкод пристрою/об'єкта, який, крім того, може легко мати частотний спектр у наднизькочастотній області. В цьому напрямі досліджень уперше, наскільки нам відомо, деякі вимірювання потенціалу з його частотним спектром були проведені для води без та зі стимуляцією (остання представлена дією магнітного поля). Цей перший комплекс вимірювань APEC 300 становить особливий інтерес для діапазону 0-0,5 Гц.

Ключові слова: вода в клітині; динамічні зміни води; біологічні та клінічні наслідки; електричні параметри шкіри; електроакупунктура Фолля; AРEC 300 і високочутливе вимірювання; низькі концентрації препаратів; потенційні вимірювання і частотний спектр; пам'ять води.

М. Скалья, П. Авино, М. Сперини, В. Виккаро, А. Писани, В.И. Валенси

\section{НЕКОТОРЫЕ НАБЛЮДЕНИЯ ОТНОСИТЕЛЬНО РОЛИ СОСТОЯНИЙ ВОДЫ В БИОЛОГИЧЕСКИХ И ТЕРАПЕВТИЧЕСКИХ ЭФФЕКТАХ}

Обнаруженные особенные свойства воды, в том числе “память воды", акцентируют внимание на поведении воды в клетке, "упорядоченная" структура которой, вероятно, обусловлена эндогенными электромагнитными полями, генерируемыми органеллами внутри клеток, такими как митохондрии и микротрубочки. Сообщается о биологических и клинических последствиях динамических изменений воды, главным образом на основе анализа SEP (Skin Electric Parameters), и выдвигается гипотеза о "действии на расстоянии", оказываемом препаратами низкой концентрации. В настоящее время касательно измерения электрокожных параметров наше исследование может прибегнуть к устройству современной электроники AРEC 300, которое наряду с электроакупунктурой по Фоллю, но с количественными точными значениями, может обнаруживать микроизменения параметров водных растворов клетки, а также воды, когда анализируемый объект подвергается действию внешнего электромагнитного слабого поля, равно как и препарата при очень низкой концентрации. В выводах излагается проект двух возможных направлений исследований, один из которых зависит только от нас самих и от “испытаний воды” в контексте экспериментов с "памятью воды". Наряду с экспериментами СЭИ по проводимости и импедансной спектроскопии, в работе с использованием АРЕС 300 предлагаются очень высокочувствительные измерения важного параметра - потенциала; своего рода измерения, менее сложные и более надежные в отношении помех устройства/объекта, который, кроме того, может легко располагать частотным спектром в сверхнизкочастотной области. В этом направлении исследований впервые, насколько нам известно, некоторые измерения потенциала с его частотным спектром были проведены для воды без и со стимуляцией (последняя представлена действием магнитного поля). Этот первый комплекс измерений APEC 300 представляет особый интерес для диапазона 0-0,5 Гц.

Ключевые слова: вода в клетке; динамические изменения воды; биологические и клинические последствия; электрические параметры кожи; электроакупунктура Фолля; АРЕС 300 и высокочувствительное измерение; низкие концентрации препаратов; потенциальные измерения и частотный спектр; память воды. 